Volume 13. Number 1. June 2018 Page 50-62

\title{
Aspek Yuridis Perlindungan Hukum dan Pemenuhan Hak Penyandang Disabilitas
}

\author{
Anak Agung Istri Ari Atu Dewi ${ }^{凶}$
}

Fakultas Hukum Universitas Udayana, Bali, Indonesia

DOI: http://dx.doi.org/10.15294/pandecta.v13i1.13933

\begin{abstract}
Article info
Abstrak

Article History:

Received: March 2018;

Accepted: June 2018;

Secara empiris, penyandang disabilitas sering mendapat pelakuan diskriminatif

Published: June 2018

dalam kehidupan sosial yang berakibat pada pengabaian terhadap terpenuhinya hak hak penyandang disabilitas, meskipun secara yuridis, seperti di Bali, telah ada produk hukum Daerah yang memberikan perlindungan terhadap hak-hak penyan-

Keywords:

legal protection;

fulfilment; dang disabilitas. Penelitian ini bertujuan untuk menganailisis bagaimana bentukbentuk perlindungan hukum yang diberikan kepada penyandang disabilitas dan bagaimana pelaksanaan hak-hak penyandang disabilitas tersebut dikaitkan dengan budaya Bali. Penelitian ini menggunakan metode penelitian normatif dengan pendekatan peraturan perundang-undangan (statue approach) dan pendekatan konsep. Hasil penelitian ini menunjukkan bahwa perlindungan hukum dan pemenuhan hak penyandang disabilitas yang diatur melalui Perda Provinsi Bali Nomor 9 Tahun 2015 telah memuat hak-hak penyandang disabilitas yang cukup komprehensif, serta juga memuat kewajiban dari Pemerintah Daerah dalam melakukan pemenuhan hak penyandang disabilitas. Namun, demikian dalam hak keberagamaan penyandang disabilitas, memilik potensi untuk tidak dapat diterapkan karena cenderung tidak sejalan dengan adat dan budaya Bali yang sudah turun-temurun.
\end{abstract}

\begin{abstract}
Empirically, people with disabilities often get discriminatory treatment in social life which results in neglect of the fulfillment of the rights of persons with disabilities, although juridically, as in Bali, there are already regional legal products that provide protection for the rights of persons with disabilities. This study aims to analyze how forms of legal protection given to people with disabilities and how the implementation of the rights of persons with disabilities is associated with Balinese culture. This study uses normative research methods with the approach of legislation (statue approach) and conceptual approach. The results of this study indicate that legal protection and the fulfillment of the rights of persons with disabilities regulated through the Bali Provincial Regulation Number 9 of 2015 has contained the rights of persons with disabilities that are quite comprehensive, as well as the obligations of the Regional Government in fulfilling the rights of persons with disabilities. However, as in the rights of religious persons with disabilities, they have the potential not to be applied because they tend to be inconsistent with Balinese customs and culture that has been passed down through generations.
\end{abstract}




\section{Pendahuluan}

Penyandang disabilitas merupakan salah satu kelompok rentan dan minoritas yang jumlahnya mencapai 600 juta orang atau $2 / 3$ dari keseluruhan penduduk yang berada di negara berkembang. Selama tiga dekade awal keberadaan PBB, eksistensi para penyandang disabilitas terabaikan. Buktinya adalah bahwa para perancang Internasional Bill of Human Rights tidak memasukan penyandang disabilitas sebagai kelompok rentan terhadap pelanggaran HAM (Degener, 2000:187). Di Dalam Deklarasi Universal Hak Asasi Manusia Tahun 1948, Konvenan Internasional tentang Hak-Hak Sipil dan Politik Tahun 1966 dan Konvenan Inernasional tentang Ekonomi, Sosial dan Budaya Tahun 1966 yang secara eksplisit memyebutkan disabilitas sebagai katagori yang dilindungi. Selanjutnya dapat dipahami bahwa kata disbilitas yang dirujuk sebagai isu HAM dalam berbagai dokumen hanya berkaitan dengan jaminan sosial dan kebijakan kesehatan preventif.

Di sisi lain, di dalam Program Aksi Dunia Penyandang Disabilitas Tahun 1982, komponen hak yang sama dari kebijakan hukum dan hak penyandang disabilitas menjadi target utama dari gerakan hak-hak penyandang disabilitas Internasional (Putusan MK Nomor 10-17-23/PUU-VII/2009 perihal Pengujian Undang-Undang Nomor 44 Tahun 2008 tentang Pornografi terhadap UndangUndang Dasar Tahun 1945). Kejelasan komitmen Internasional tersebut menunutut
Pemerintah Indonesia untuk mewujudkan tercapinya program aksi yaitu menghapus isu diskriminasi terhadap kaum penyandang disabilitas.

Berdasarkan data Rencana Strategis Kementerian Sosial Republik Indonesia dan RPJM 2010-2015 memberi perhatian bahwa penyandang disabilitas yang menjadi sasaran kebijakan dan program Pemerintah di Indonesia adalah 1.163.508 jiwa.

Fakta sosiologis menunjukan bahwa penyandang disabilitas sering mendapat perlakuan yang diskriminasi, hal ini dapat ditunjukkan bahwa konsep disabilitas sering disebut dengan orang cacat yang dianggap sebagai warga yang tidak produktif, tidak mampu menjalankan tugas dan tanggungjawabnya. Oleh karena itu Diskriminasi terhadap penyandang disabilitas berdampak pada tidak terpenuhinya hak-hak penyadang disabilitas.

Pengabaian hak-hak penyandang disabilitas merupakan perlakuan diskriminasi yang menimbulkan berbagai manifestasi ketidakadilan diantaranya: pemiskinan ekonomi terhadap kaum disabilitas, subordinasi terhadap kaum disabilitas baik dalam rumah tangga, masyarakat, maupun Negara, pelabelan negatif (stereotype) terhadap kaum disabilitas, tidak dibukanya akses sarana publik bagi kaum disabilitas dan terbatasnya akses sosial dan budaya serta fisik bagi kaum disabilitas. Berdasarkan data sosilogis di Provinsi Bali, nampaknya penyandang disabilitas juga di

Tabel 1.Banyaknya Penderita Cacat Menurut Kabupaten/Kota

\begin{tabular}{|c|c|c|c|c|c|}
\hline Kabupaten/Kota & Tuna Netra & $\begin{array}{c}\text { Tuna } \\
\text { Wicara }\end{array}$ & $\begin{array}{c}\text { Cacat Anggota } \\
\text { Badan } \\
\end{array}$ & $\begin{array}{l}\text { Cacat } \\
\text { Mental }\end{array}$ & $\begin{array}{c}\text { Jompol/ } \\
\text { Lanjut Usia }\end{array}$ \\
\hline 1. Jembrana & 105 & 242 & 1715 & 215 & 1598 \\
\hline 2. Tabanan & 190 & 379 & 1815 & 375 & 995 \\
\hline 3. Badung & 360 & 280 & 804 & 208 & 159 \\
\hline 4. Gianyar & 222 & 293 & 1128 & 336 & 691 \\
\hline 5. Klungkung & 146 & 256 & 686 & 233 & 1313 \\
\hline 6. Bangli & 724 & 729 & 1366 & 563 & 4163 \\
\hline 7. Karangasem & 273 & 357 & 1995 & 236 & 1577 \\
\hline 8. Buleleng & 1547 & 2589 & 2049 & 1941 & 7362 \\
\hline 9. Denpasar & 63 & 142 & 314 & 137 & 169 \\
\hline Jumlah & 3630 & 5267 & 11872 & 4244 & 18027 \\
\hline
\end{tabular}

Sumber: Dinas Sosial Provinsi Bali 
data untuk mengetahui seberapa banyak penyandang disabilitas di Provinsi Bali. Pendataan tersebut merupakan pendataan penyandang disabilitas pada setiap Kabupaten/Kota di Bali.

Berdasarkan data pada Tabel 1, dapat digambarkan bahwa jenis penyandang disabilitas ada lima yaitu tuna netra, tuna wicara, cacat anggota badan, cacat mental dan jompol/lamjut usia. Berdasarkan data yang disajikan di atas, penderita cacat yang terbanyak adalah cacat lanjut usia yang mencapai 18.027 orang. Berdasarkan gambaran data di atas juga menunjukan bahwa di Provinsi Bali penyandang disabilitas sungguh mencengangkan, sampai melebih angka 18.000.

Selanjutnya perlu juga di gambarkan data yang berkaitan banyaknya penderita cacat atau penyandang disabilitas yang mendapat santunan sebagaimana terlihat pada tabel 2.

Tabel 2. Penyandang disabilitas yang mendapat santunan

\begin{tabular}{cr}
\hline Tahun & Penderita Cacat \\
\hline $1996 / 1997$ & 3353 \\
$1997 / 1998$ & 2241 \\
$1998 / 1999$ & 718 \\
$1999 / 2000$ & 804 \\
2000 & 12598 \\
2001 & 12766 \\
2002 & 13150 \\
2003 & 13444 \\
2004 & 23517 \\
2005 & 37657 \\
2006 & 28199 \\
\hline
\end{tabular}

Sumber: Dinas Sosial Provinsi Bali, 2007.

Berdasarkan data pda tabel 2 terlihat bahwa penyadang disabilitas di Bali cukup banyak dalam kehidupan masyarakat. Untuk itu perlu dilakukan suatu kajian yang melihat dari aspek normative terkait dengan perlindungan hukum terhadap penyandang disabilitas serta pengaturan mengenai pemenuhan hak-hak penyandang disabilitas di Provinsi Bali.

Berkaitan dengan perlindungan hukum, bahwa para penyandang disabilitas berhak untuk dapat diberikan perlindungan hukum secara optimal sebagai mana di atur dalam Pasal 9 Undang Undang Nomor 8 Tahun 2016 tentang Penyandangg Disabilitas. Dalam ketentuan Pasal 9 UU Nomor 8 Tahun 2016 secara tegas dinyatakan bahwa penyandang disabilitas berhak mendapatkan perlindungan dari tekanan-tekanan, kekerasan, penganiayaan, diskriminasi dan perampasan (pengalihan hak milik). Menarik untuk dicermati Pasal 130 UU Nomor 8 Tahun 2016 yang menentukan Pemerintah Daerah membentuk mekanisme koordinasi di tingkat Provinsi dan Kabupate/Kota terkait dengan penghormatan, perlindungan dan pemenuhan penyandang Disabilitas. Pasal 130 UU Nomor 8 Tahun 2016 dipahami bahwa ada koordinasi yang jelas antara pemerintah Provinsi dan Pemerintah Kabupaten/Kota terkait dengan langkah-langkah dalam memberikan penghormatan, perlindungan serta pemenuhan hak penyandang disabilitas.

Pemahaman Pasal 130 UU Nomor 8 Tahun 2016 menjadi suatu kewajiban bagi Pemerintah provinsi dan Pemerintah Kabupaten/Kota dalam upaya melindungi dan memenuhi berbagai hak penyandang disabilitas. Dalam konteks tulisan ini perlu dikaji mendalam terkait dengan tindakan Pemerintah Provinsi Bali terkait dengan perlindunggan dan pemenuhak hak-hak penyandang disabilitas. Hal ini dapat dimaknai bahwa UU nomor 8 Tahun 2016 mengharuskan adanya perlindungan dan pemenuhan hak penyandang disabilitas.

Berdasarkan uraian di atas, urgensi dalam tulisan ini untuk melihat dan mengkaji terkait dengan upaya Pemerintah Daerah Provinsi Bali dalam perlindungan dan pemenuhan hak-hak penyandang disabilitas melalui produk hukum daerah, sehingga terpenuhinya tuntutan internasional dan nasional dalam program aksi yaitu menghapus isu diskriminasi terhadap kaum penyandang disabilitas, sehingga tercapainya keadilan bagi penyandang disabilitas.

Penelitian ini bertujuan untuk menganalisis penggaturan perlindungan dan pemenuhan hakpenyandang disabilitas dalam produk hukum daerah di Pemerintah Daerah 
Provinsi Bali, dan menganalisis bentuk-bentuk yang dilakukan oleh Pemerintah Daerah Provinsi Bali dalam pemenuhan hak-hak penyandang disabilitas.

\section{Metode Penelitian}

Penelitian merupakan upaya pencarian daam pengembangan ilmu pengetahuan. Peter Mahmud Marzuki menegaskan bahwa penelitian hukum merupakan suatu proses dalam menemukan prinsip-prinsip, doktrin guna menjawab isu hukum (Marzuki, 2005:35). Selanjutnya Morris L. Cohen dan Kent C. Olson menegaskan bahwa penelitian hukum merupakan proses menemukan hukum, menjelaskan dan menganalisis hukum (Cohen dan Oslon, 2000:1). Soerjono Soekanto (1986:51) mengemukakan terdapat dua (2) jenis metode penelitian yaitu penelitian hukum normatif dan penelitian sosiologis atau penelitian empiris. Dalam tulisan ini digunakan penelitian normatif atau penelitian doktrinal. Penelitian doktrinal lebih banyak dilakukan diperpustakaan atau studi dokumen. Penelitian ini lebih banyak dilakukan pada bahan hukum yang ada diperpustakaan (Waluyo, 1991:31). Jenis penelitian normatif dalam konteks ini digunakan untuk membedah permasalahan yang berkaitan dengan Produk hukum daerah perlindungan dan pemenuhan hak penyandang disabilitas.

Sumber bahan hukum yang digunakan dalam penelitian ini meliputi bahan hukum primer dan bahan hukum sekunder. Bahan hukum primer berupaUUD NRI Tahun 1945, UU No. 19 Tahun 2011 tentang Pengesahan Conventoin on the Rights of Persons with Disabilities (Konvensi Mengenai Hak-Hak Penyandang Disabillitas, UU No. 8 Tahun 2016 tentang Penyandang Disabilitas dan Peraturan Daerah. Bahan hukum sekunder berupa buku-buku yang terkait, jurnal hukum, makalah hukum.

Teknik pengolahan dan analisis bahan hukum dilakukan dengan mengolah dan menganalisis bahan hukum primer dan bahan hukum sekunder yang telah terkumpul yang selanjutnya dikatagorikan dan dikualifikasikan berdasarkan permasalahan peneliti dan disusun secara sistematis sesuai dengan kerangka yang telah disiapkan sebelumnya. Pada tahap analisis, bahan hukum yang telah dikatagorikan dan dikualifikasikan diinterpretasi dengan menggunakan hermeneutika hukum (Irianto, 2009:181). Hermeneutika hukum pada prinsipnya merupakan metode interpretasi teks hukum yang berkaitan dengan konteks. Hermeneutika hukum digunakan untuk mengungkap makna dan gagasan yang tersirat dalam teks hukum atau teks norma. Hermeneutika hukum penting dilakukan untuk melakukan konfirmasi dan konfrontasi dengan teori, konsep dan pemikiran para sarjana yang mempunyai otoritas dan berkaitan dengan tematik penelitian ini (Atmaja, 2012:17-18). Keseluruhan hasil analisis, selanjutnya disajikan secara deskriptif yaitu dengan memaparkan secara lengkap segala persoalan yang terkait dengan masalah yang diteliti disertai dengan memberikan ulasan-ulasan secara kritis.

\section{Hasil Penelitian dan Pembahasan}

\section{Konsep Perlindungan HAM disabilitas}

Perlindungan hukum merupakan hal terpenting dari negara hukum. Hal tersebut dianggap penting oleh karena dalam pembentukan suatu negara maka juga akan di bentuk hukum yang berfungsi mengatur prilaku setiap warga negaranya. Dengan demikian perlindungan hukum merupakan kewajiban suatu negara untuk memberikan perlindungan hukum kepada setiap warga negaranya. Selanjutnya Perlindungan hukum juga dapat dipahami bahwa suatu perlindungan yang dapat diberikan kepada subyek hukum ke dalam bentuk perangkat baik yang bersifat preventif maupun yang bersifat represif, baik yang lisan maupun yang tertulis. Dengan kata lain dapat dikatakan bahwa perlindungan hukum sebagai suatu gambaran tersendiri dari fungsi hukum itu sendiri, yang memiliki konsep bahwa hukum memberikan suatu keadilan, ketertiban, kepastian, kemanfaatan dan kedamaian.

Pemahaman konsep perlindungan hukum diuraikan oleh beberapa ahli seperti: pertama, Satjipto Raharjo memahami konsep perlindungan hukum merupakan tindakan untuk memberikan pengayoman kepa- 
da pihak yang dirugikan dan dilanggar hak asasinya serta perlindungan itu diberikan kepada masyarakat untuk dapat menikmati hak-haknya yang diberikan oleh hukum (Rahardjo, 1983:121). Kedua, Philipus M. Hadjon (1987:38) juga berpendapat bahwa perlindungan hukum tersebut merupakan perlindungan terhadap harkat dan martabat serta pengakuan terhadap hak asasi manusia. Selanjutnya Hadjon juga menambahkan bahwa perlindungan hukum merupakan kumpulan peraturan atau kaidah yang dapat melindungi hal-hal lainnya. Ketiga, Menurut CST Kansil menyebut bahwa perlindungan hukum dikatakan sebagai upaya hukum yang diberikan penegak hukum dalam hal memberikan rasa aman baik secara phisik dan phisikis kepada masyarakat. Keempat, Muktie, A. Fadjar menegaskan bahwa perlindungan hukum merupakan perlindungan yang diberikan oleh hukum yang berkaitan dengan hak dan kewajiban.

Pemahaman konsep perlindungan hukum, apabila dikaitkan dengan perlindungan penyandang disabilitas, maka dalam ruang lingkup yuridis, obyek kajiannya adalah berbagai ketentuan hukum dan norma-norma yang berlaku di masyarakat terutama berkaitan dengan perlindungan penyandang disabilitas dan pemenuhan hak hak mereka. Dengan demikian perlindungan hukum terhadap penyandang disabilitas yang bersifat yuridis ini menyangkut semua aturan hukum yang mempunyai dampak langsung bagi kehidupan dan pemenuhan hak-hak di penyandang disabilitas. Aspek hukum perlindungan penyandang disabilitas, diberi batasan-batasan sebagai berikut: a. Hukum perlindungan hak-hak disabilitas sebagai hukum. b. Aspek hukum perlindungan hak-hak disabilitas diatur dalam hukum (HAM) (Zein, tth.,:51-52). Perlindungan hak penyandang disabilitas merupakan suatu usaha yang menempatkan kondisi dimana setiap penyandang disabilitas dapat melaksanakan hak dan mengakses setiap sarana dan prasarana umum. Oleh karena itu dengan perlindungan hukum terhadap hak-hak disabilitas dapat mewujudkan kepastian dan keadilan penyandang disabilitas.

\section{Konsep Pemenuhan Hak}

Berbicara pemenuhan hak bagi penyandang disabilitas berarti berbicara menyangkut kewajjiban Negara dalam pemenuhan hak-hak kaum disabilitas. Dalam Konvensi CRPD menetapkan bahwa bahwa negara peserta wajib merealisasikan hak-hak yang termuat dalam konvensi tersebut dengan cara menyesuaikan peraturan perundangundangan dan praktik-praktik yang menghapus diskriminasi penyandang disabilitas serta harus menjamin partisipasi penyandang disabilitas dalam segala aspek kehidupan seperti pendidikan, kesehatan, pekerjaan sampai informasi dan komunikasi (2016). Hal ini, tampaknya dipertegas dalam Pasal 4 Konvensi CRPD yang menegaskan negara wajib mengadopsi ketentuan CRPD ke dalam kebijakan legislatif dan administrative. Dalam konteks ini Bangsa Indonesia harus menyesuaikandan menyingkronkan peraturan perundangundangan sebagaimana diatur dalam ketutan CRPD.

Dalam pelaksanaan kewajiban tersebut, Negara Indonesia mengacu pada prinsip- prinsip umum yakni: penghormatan pada martabat manusia; nondiskriminasi; partisipasi; menghormati atas perbedaan dan penerimaan penyandang disabilitas; akses; kesetaraan kesempatan; dan kesetaraan lakilaki dan perempuan.

Selanjutnya dalam Pasal 1 angka 6 Undang-Undang Nomor 8 Tahun 2016 tentang Penyandang Disabilitas menyatakan bahwa Pemenuhan adalah upaya yang dilakukan untuk memenuhi, melaksanakan, dan mewujudkan hak Penyandang Disabilitas. Difinisi konsep ini memperjelas bahwa dalam melakukan pemenuhan hak juga disukung oleh pelaksanaan untuk mewujudkan pemenuhan hak tersebut.

Keterkaitan konsep pemenuhan dalam konteks pemenuhan hak-hak penyandang disabilitas adalah bahwa kaum disabilitas adalah orang yang mempunyai hak asasi yang harus diakui, dilindungi dan dipenuhi hak-haknya. Pemenuhan hak yang dimaksud adalah bahwa apa yang menjadi hak bagi masyarakat umum atau (orang normal) juga menjadi hak bagi kaum disabilitas. Pemenu- 
han hak ini ditempatkan pada pemenuhan hak atas pendidikan, ekonomi, social, budaya, politik serta lapangan pekerjaan. Kewajiban pemerintah yang berupa tindakan pemerintah dalam pemenuhan hak para penyandang disabilitas, tidak hanya cukup pada aspek pengaturan dalam produk hukum, namun perlu juga tindakan pemerintah dalam pemenuhan hak-hak penyandang disabilitas dari aspek pelaksanaannya.

\section{Penyandang Disabilitas}

Di dalam Kamus Besar Bahasa Indonesia (2008) kata penyandang diartikan sebagai orang yang menyandang (menderita) sesuatu. Disabilitas merupakan serapan bahasa Inggris disability (jamak: disabilities) diartikan sebagai kecacatan atau ketidakmampuan. Menurut Undang-Undang Nomor 19 Tahun 2011 Tentang Pengesahan Hak-Hak Penyandang Disabilitas, penyandang disabilitas merupakan orang yang memiliki keterbatasan fisik, mental, intelektual atau sensorik dalam jangka waktu lama yang dalam berinteraksi dengan lingkungan dan sikap masyarakatnya dapat menemui hambatan yang menyulitkan untuk berpartisipasi penuh dan efektif berdasarkan kesamaan hak.

Selanjutnya Pasal 1 angka 1 UndangUndang Nomor 8 Tahun 2016 tentang Penyandang Disabilitas menegaskan penyandang disabilitas merupakan setiap orang mengalami keterbatasan fisik, intelektual, mental atau sensorik dalam jangka waktu lama dan mengalami hambatan dan kesulitan dalam berinteraksi. Memahami difinisi konsep penyandang disabilitas di atas, maka orangorang yang berkebutuhan khusus atau disabilitas merupakan orang yang hidup dengan karakteristik khusus dan memiliki perbedaan dengan orang pada umumnya. Oleh karena itu memerlukan suatu pelayanan yang khusus atau berbeda agar terpenuhi hak-haknya.

Pengaturan perlindungan dan pemenuhan hak peyandang disabilitas dalam produk hukum daerah

Pemahaman tentang konsep perlindungan dan pemenuhan hak penyandang disabilitas dapat diawali dengan pemahaman konsep dari Gustav Radbruch. Gustav Rad- bruch membedakan konsep hukum menjadi 2 (dua) yaitu konsep yuridik relevan (legally relevant concepts) dan konsep yuridik asli (genuine legal concepts). Konsep yuridik relevan diartikan sebagai konsep yang merupakan komponen aturan hukum, khususnya konsep yang digunakan memaparkan situasi fakta dalam ketentuan Peraturan perundang-undangan yang dijelaskan dengan interpretasi. Selanjutnya konsep hukum asli (genuine legal concepts) merupakan konsep konstruktif dan sistematis yang digunakan untuk memahami sebuah aturan hukum (Shidarta, 2009:142).

Berdasarkan konsep yuridik relevan dalam mengalisis perlindungan dan pemenuhan hak penyandang disabilitas, maka hal pertama yang dilakukan adalah dengan melakukan penelusuran konsep dalam Peraturan Perundang-undangan.

Perlindungan sebagaimana diuraikan Satjipto Raharjo yang mengartikan konsep perlindungan merupakan suatu tindakan dalam memberikan pengayoman bagi mereka yang terlanggar hak asasinya baik oleh negara maupun orang lain (Rahardjo, 1983). Dalam pandangan Satjipto Rahadjo, penekanannya adalah dalam memberikan pengayoman kepada masyarakat untuk terpenuhinya hak asasi manusia serta dapat menikmati hak-hak asasi penyandang disabilitas yang telah diatur dalam ketentuan hukum. Konsep perlindungan dapat dilihat dalam ketentuan Pasal 1 angka 5 Undang-Undang Nomor 8 Tahun 2016 tentang Penyandang disabilitas yang menegaskan bahwa perlindungan pada penyandang disabilitas merupakan upaya yang dilakukan secara sadar untk dapat melindungi, mengayomi dan memperkuat hak penyandang disabilitas. Pemahaman Pasal 1 angka 5 UU 8 Tahun 2016 menegaskan bahwa upaya pemerintah daerah melakukan perlindungan adalah dengan mengayomi penyandang disabilitas. Prinsip pengayoman tersebut adalah memberikan perlindungan hukum dan pemenuhan hak bagi penyandang disabilitas tanpa diskriminasi.

Konsep yuridik terkait dengan pemenuhan hak penyandang disabilitas ditemukan dalam Pasal 1 angka 6 Undang-Undang Nomor 8 tahun 2016 yang menentukan bahwa 
pemenuhan hak penyandang disabilitas dipahami sebagai upaya pemerintah yang dilakukan untuk memenuhi, melaksanakan, dan mewujudkan hak Penyandang Disabilitas. Berkaitan dengan upaya pemerintah dalam pemmenuhan hak penyandang disabilitas diatur dalam Pasal 27 Undang-Undang Nomor 6 Tahun 2016 yang menentukan bahwa Pemerintah berkewajiban untuk melakukan perencanaan, pelaksanaan, evaluasi, pelaksanaan penghormatan, perlindungan dan pemenuhan hak penyandang disabilitas. Dalam upaya pemerintah melakukan pemenuhan hak penyandang disabilitas, pemerintah berkewajiban menuangkan dan merumuskan pengaturan hak-hak penyandang disabiitas dalam rencana induk. Pasal 27 Undang-Undang Nomor 6 Tahun 2016 dimaknai bahwa ada kewajiban pemerintah maupun pemerintah daerah untuk melakukan pemenuhan hak penyandang disabilitas. Ketentuan pemenuhan hak penyandang disabilitas sebelumnya dituangkan terlebih dahulu dalam rencana induk dan selanjutnya dijabarkan dalam kebijakan hukum yang lebih rendah, baik itu kebijakan hukum daerah atau produk hukum daerah.

Pengaturan perlindungan dan pemenuhan hak disabilitas dapat dilihat dalam hierarki Peraturan perundang-undangan. Dalam Pasal 7 ayat (1) UU 12 ahun 2011 disebutkan bahwa hierarki peraturan perundang-undangan terdiri dari:

a. UUD NRI Tahun 1945;

b. Ketetapan MPR;

c. UU/Perpu;

d. PP;

e. Perpres;

f. Perda Provinsi;

g. Perda Kabupaten/Kota.

Di dalam pemahaman hierarki, pada prinsipnya peraturan yang lebih rendah tidak boleh bertentangan dengan peraturan yang lebih tinggi. Pemahaman hierarki menurut Ni Matul Huda menggambarkan bahwa Peraturan Daerah tidak boleh bertentangan dengan Peraturan perundang-undangan yang lebih tinggi tingkatannya atau the supreme law of the land (Huda, 2006:28).

Secara teoritik, hierarki peraturan pe- rundang-undangan dalam ajaran Hans Kelsen disebut Stufenbau des Recht atau the hierarchy of law yang menyebutkan bahwa kaidah hukum merupakan suatu susunan berjenjang dan setiap kaidah hukum yang lebih rendah bersumber dari kaidah yang lebih tinggi. Untuk lebih memahami teori stufenbau des recht harus dihubungkan dengan ajaran Kelsen yang lain yaitu Reine Rechtslehre atau the pure theory of law (teori murni tentang hukum) bahwa hukum itu tidak lain "command of the sovereign" kehendak yang berkuasa (Manan, 2004:203). Memahami bahwa hukum merupakan kehendak penguasa dimaknai sebagai hukum yang merupakan sistem norma yang dinamis, dalam arti norma hukum dibentuk dan dihapus oleh lembaga yang membentuknya (Kelsen, 1973:112113). Dengan demikian hukum adalah sah (valid) apabila dibuat oleh lembaga atau otoritas yang berwenang membentukknya.

Berdasarkan pada pemahaman tata urutan peraturan perundang-undangan dapat ditarik prinsip-prinsip sebagai berikut:

1. Peraturan perundang-undangan yang lebih tinggi kedudukannya dapat dijadikan landasan atau dasar hukum bagi peraturan perundang-undangan yang lebih rendah;

2. Peraturan perundang-undangan yang lebih rendah harus bersumber atau memiliki dasar hukum dari peraturan perundang-undangan yang lebh tinggi;

3. Isi atau muatan peraturan perundangundangan yang lebih rendah tidak boleh menyimpang dari isi atau norma aturan yang lebih tinggi;

4. Suatu peraturan perundang-undangan hanya dapat dicabut atau diganti oleh oleh peraturan perundang-undangan yang lebih tinggi atau sederajat;

5. Perauran perundang-undangan yang sejenis apabila mengatur materi yang sama, maka peraturan yang terbaru harus diberlakukan, walaupun tidak dengan secara tegas dinyatakan bahwa peraturan yang lama itu dicabut;

6. Peraturan yang mengatur materi yang lebih khusus harus diutamakan dari peraturan perundang-undangan yang lebi umum (Ranggawidjaja, 1986:19). 
Prinsip-prinsip sebagaimana di jelaskan di atas digunakan sebagai cara atau teknik dalam menganlisis pengaturan perlindungan dan pemenuhan hak penyandang disabilitas. Analisis mengenai pengaturan perlindungan hukum dan pemenuhan hak penyandang disabilitas dimulai dari pemahaman tujuan negara yang terdapat dalam Pembukaan UUD NRI Tahun 1945 dalam alenia ke 4 yang menyebutkan bahwa "... Negara Indonesia melindungi segenap bangsa Indonesia dan seluruh tumpah darah Indonesia...". Makna ini dipahami bahwa dalam melindungi seluruh warga negara Indonesia tidak boleh ada diskriminasi atau pembedaan baik beradarkan atas keadaan fisik dan metal. Dalam hal ini negara harus menjamin persamaan tanpa ada diskriminasi terhadap seluruh warga negara Indonesia. Dengan demikian negara Indonesia tegas mengakui hak para kaum disabilitas. Oleh karena itu negara berkewajiban melakukan perlindungan hukum bagi kaum disabilitas. Selanjutnya penjabaran dari tujuan negara dalam memberi perlindungan pada kaum disabilitas dituangkan dalam Pasal 28 D ayat (1) yang menegaskan bahwa setiap warga negara berhak atas pengakuan, jaminan, perlindungan, dan kepastian hukum yang adil dan berhak mendapat perlakuan yang sama di dihadapan hukum. Pemahaman Pasal 28 D ayat (1) ini dipahami bahwa bagi kaum disabilitas dalam konteks ini mewajibkan negara dalam memberi perlindungan hukum, perlakuan yang sama di hadapan hukum termasuk kewajiban negara dalam memberikan pemenuhan hak penyandang disabilitas tanpa diskriminasi.

Perlindungan dan pemenuhan hak penyandang disabilitas juga telah diatur dalam UU Nomor 19 Tahun 2011 tentang Pengesahan Convention on the Rights of Persons Disabilities (Konvensi Mengenai Hak-Hak Penyandang Disabilitas). UU Nomor 19 Tahun 2011 merupakan ratifikasi dari Convention on the Rights of Person with Disabilities. Pada prinsipnya Convention on the Rights of Person with Disabilities memuat substansi pokok antara lain:

1. pengakuan hak yang sama bagi penyandang disabilitas.

2. Melindungi dan menjamin persamaan hak dan kebebasan penyandang disabilitas, serta menghormati martabat penyandang disabilitas sebagai bagian yang tidak terpisahkan (inherent dignity).

3. Negara berkewajiban menyesuaikan peraturan perundang-undangan dengan konvensi mengenai hak penyandang disabilitas.

4. Setiap penyandang disabilitas terbebas dari penyiksaan atau perlakuan tidak manusiawi yang merendahkan martabat manusia.

Berdasarkan pemahaman UU Nomor 19 Tahun 2011 tersebut jelas menggambarkan bahwa negara sungguh-sungguh ingin melindungi dan memenuhi hak kaum disabilitas. Pengaturan selanjutnya dapat dilihat dalam Undang-Undang Nomor 8 Tahun 2016 tentang Penyandang Disabilitas. Di dalam konsidran menimbang jelas digambarkan adanya tujuan filosofis, sosiologis dan yuridis. Di dalam konsidran menimbang huruf a menegaskan bahwa kaum disabilitas memiliki hak yang sama dengan warga negara lainnya untuk kehidupan yang lebih maju dan adil serta bermartabat. Selanjutnya gambaran secara sosiologis menunjukkan bahwa keadaan penyandang disabilitas dalam kondisi yang rentan, terkebelakang dan/atau miskin yang disebabkan masih adanya pembatasan, hambatan, kesulitan atau penghilangan hak penyandang disabilitas. Berdasarkan gambaran sosiologis kaum disabilitas di Indonesia memerlukan pengaturan terkait dengan perlindungan dan pemenuhan hak penyandang disabilitas sebagaimana diamanatkan oleh UUD NRI Tahun 1945.

Pengaturan perlindungan dan pemenuhan hak penyandang disabilitas diatur dalam UU Nomor 8 tahun 2016 ini, yang sarat mengatur mengenai persamaan kesempatan, tidak boleh adanya diskriminasi, penghormatan, perlindungan, pemenuhan, pemberdayaan, aksesibilitas, unit layanan disabilitas. Menarik dicermati dalam UU Nomor 8 Tahun 2016 mengenai perlindungan dan pemenuhan hak penyandang disabilitas, pengatuan dalam Pasal 9 UU Nomor 8 Tahun 2016 jelas diatur mengenai keadilan hukum dan perlin- 
dungan hukum. Bahwa hak atas keadilan hukum dan perlindungan hukum yang meliputi hak penyandang disabilitas diantaranya:

a. Hak perlakuan yang sama di hadapan hukum;

b. Pengakuan sebagai subjek hukum;

c. Memiliki dan mewarisi harta bergerak atau tidak bergerak;

d. Berhak menyelesaikan masalah dan menunjuk orang untuk mewakili kepentingannya;

e. Hak atas akses terhadap pelayanan jasa perbankan dan nonperbankan;

f. Berhak dalam akses dalam pelayanan peradilan;

g. Hak atas perlindungan dari segala tekanan, kekerasan, penganiayaan, diskriminasi dan/atau perampasan atau pengambilan hak milik;

h. Berhak dilindungi hak kekayaan intelektualnya.

Di dalam pemenuhan Pasal 9 UU Nomor 8 Tahun 2016, Pemerintah dan pemerintah derah wajib menjamin dan melindungi hak penyandang disabilitas sebagai subjek hukum untuk melakukan tindakan hukum yang sama dengan lainnya serta berhak mendapat bantuan hukum. Pengaturan perlindungan dan pemenuhan hak penyandang disabilitas dalam UU Nomor 8 Tahun 2016 bertujuan untuk mewujudkan taraf hidup penyandang disabilitas yang berkualitas, adil, sejahtera lahir dan bathin serta bermartabat. Selain itu dengan adanya pengaturan pemenuhan hak penyandang disabilitas ditujukan untuk melindungi Penyandang Disabilitas dari penelantaran dan eksploitasi, pelecehan dan segala tindakan diskriminatif, serta pelanggaran hak asasi manusia. Seturut dengan di atas, Jazim menyebutkan bahwa Indonesia harus memiliki seperangkat peraturan hukum yang adil dan tegas dalam mengatur kaum disabilitas dan pengaturan aparat yang sigap dan pro disabilitas (Hamidi, 2016:661).

Merujuk pandangan Jazim Hamidi di atas, dipahami bahwa dalam perlundungan kaum disabilitas, pemerintah berkewajiban untuk membentuk perangkat hukum yang pro disabilitas. Hal ini dimaknai bahwa Pemeintah Provinsi Bali dalam perlindungan dan pemenuhan hak penyandang disabilitas wajib membuat suatu kebijakan hukum dalam bentuk Perda, sebagai arah dan dasar dalam memberikan perlindungan dan pemenuhan hak-hak penyandang disabilitas di Bali. Selama ini pemerintah Provinsi Bali dalam memberikan perlindungan dan pemenuhan hak-hak penyandang disabilitas diatur dalam Peraturan Daerah Provinsi Bali Nomor 9 Tahun 2015 tentang Perlindungan dan Pemenuhan Hak Penyandang Disabilitas.

Dasar pertimbangan terbentuknya Perda Provinsi Bali Nomor 9 tahun 2015 tersecrmin dalam konsidran menimbang yang menegaskan untuk menjamin hak konstitusional dan untuk mengoptimalkan perlindungan dan pelayanan terhadap penyandang disabilitas. Dalam kosidran menimbang huruf a Perda Nomor 9 Tahun 2015 ini ingin mengwujudkan keadilan bagi penyandang disabilitas di segala bidang.

Di dalam Pasal 1 angka 7 Perda Provinsi Bali Nomor 9 Tahun 2015 diatur mengenai difinisi konsep penyandang disabilitas yang pada intinya menegaskan setiap orang yang meiliki gangguan, kelainan, kerusakan atau kehilangan fungsi organ fisik, mental, intelektual atau sensorik dalam jangka waktu lama yang dapat menghalangi partisipasi penuh dan efektif dalam masyarakat berdasarkan kesetaraan dengan yang lainnya.

Dalam pemahaman difinisi konsep penyandang disabilitas ini jelas bahwa disabilitas tidak hanya dimkanai sebagai orang yang kelainan kejiwaan atau kehilangan fungsi mental dan inteltualnya, melainkan juga disabilitas juga dimaknai seseorang yang fungsi organ fisiknya tidak lengkap. Dengan demikian, terhadap penyandang disabilitas sesuai dengan difinisi konsep ini, perlu mendapat perhatian dari pemerintah daerah.

Perhatian pemerintah daerah Provinsi Bali tertuang dalam upaya tindakan yang dilakukan oleh Pemerintah Provinsi Bali Dalam memberikan perlindungan dan pemenuhan hak bagi penyandang disabilitas. Ketentuan ini tertuang dalam Pasal 1 angka 9 Perda Provinsi Bali Nomor 9 Tahun 2015 yang menegaskan bahwa Pemenuhan dan Perlindungan Hak Penyandang Disabilitas adalah segala 
tindakan dan/atau kegiatan untuk menjamin dan melindungi hak konstitusional para penyandang disabilitas sesuai dengan harkat dan martabat kemanusiaan serta terhindar dari tindak kekerasan dan diskriminasi. Menarik juga dicermati Pasal 1 angka 11 yang menyatakan mengenai derajat disabilitas. Derajat disabilitas dipahami sebagai tingkat kedisabilitasan ringan, sedang maupun berat yang disandang oleh penyandang disabilitas. Mendukung Pasal 1 angka 11 dalam Pasal 3 ayat (2) Perda Provinsi Bali Nomor 9 Tahun 2015 menyebutkan ruanglingkup jenis penyandang disabilitas yaitu:

a. gangguan dalam penglihatan;

b. gangguan dalam pendengaran

c. gangguan dalam berbicara;

d. gangguan motorik dan mobilitas;

e. cerebral palsy;

f. gangguan dalam pemusatan perhatian dan hiperaktif;

g. autis;

h. epilepsi;

i. tourette's syndrome;

j. gangguan sosialitas, emosional, dan perilaku;

k. retardasi mental; dan

I. keterlambatan belajar.

Berdasarkan jenis-jenis penyandang disabilitas sebagaiman di atur dalam Pasal 3 ayat (2) Perda 9 Tahun 2015 dipahami bahwa para penyandang disabilitas sebagaimana jenisnya yang telah diatur pada huruf a sampai huruf I yang wajib dilindungi dan dipenuhi haknya oleh Pemerintah daerah Provinsi Bali. Memahami jenis-jenis penyandang disabilitas, nampak ada ketidakjelasan norma yang terkandung, karena norma tersebut tidak mengatur prediksi jenis jenis penyandang disabilitas yang lain. Sehingga dapat dipahami apabila ada jenis-jenis penyandang disabilitas yang lain maka Perda ini tidak dapat memberikan perlindungan dan pemenuhan hak bagi penyandang disabilitas. Kritik terhadap Pasal 3 ayat (2) ini dapat berdampak pada pengabaian hak penyandang disabilitas, sebagaimana ditur dalam UUD NRI Tahun 1945.

Pengaturan perlindungan dan pemenuhan hak penyandang disabilitas sebagaimana telah diuraikan di atas, dipahami sebagai suatu pengaturan yang telah jelas diatur mulai dari UUD NRI Tahun 1945, diatur dalam UU serta diatur dalam Perda Provinsi Bali. Pengaturan ini menunjukan bahwa ada upaya pemerintah maupun Pemerintah daerah untuk memberikan perlindungan dan pemenuhan hak bagi penyandang disabilitas. Namun menarik untuk dicermati, ketika menganalisis Perda 9 Tahun 2015 yang menyebutkan jenis-jenis penyandang disabilitas yang hanya mengatur 12 jenis, yang akan berdampak terjadi pengabaian pemenuhan hak penyandang disabilitas yang tidak termasuk 12 jenis penyandang disabilitas yang telah diatur dalam Perda 9 Tahun 2015.

Berkaitan dengan Pemahaman Pasal 3 ayat (2) Perda Provinsi Bali Nomor 9 Tahun 2015 ditemukan juga ketidka jelasan norma berkaitan dengan tatacara dan mekanisme dalam memberikan pemenuhan hak penyandang disabilitas. Dengan demikian menjadi pertanyaan penting apakah setiap penyandang disabilitas sudah terpenuhi haknya, lalu apa saja bentuk hak-hak penyandang disabilitas. Dengan demikian Perda Provinsi Bali Nomor 9 Tahun 2015 dipahami sebagai Perda yang masih menyisakan problem-problem yang berkaitan dengan perlindungan dan pemenuhan hak penyandang disabilitas. Pemahaman Perda Provinsi Bali Nomor 9 Tahun 2015 secara teoritik masih mengandung problematik yang mengakibatkan terabainya hak penyandang disabilitas.

Bentuk-Bentuk Pemenuhan Hak Penyandang Disabilitas.

Sebagaimana yang telah di atur dalam Konstitusi, bahwa setiap warga negara mempunyai kedudukan hukum dan memiliki hak asasi manusia yang sama sebagai Warga Negara Indonesia dan sebagai bagian yang tidak terpisahkan dari warga negara dan masyarakat Indonesia. Makna yang terkandung dalam konstitusi tentu saja harus dijabarkan dalam peraturan perundang-undangan yang lebih rendah. Dalam konteks ini adalah UU 8 Tahun 2016 tentang Penyandang Disabilitas. Penjabaran makna persamaan HAM yang tertuang dalam Konstitusi, nampaknya sudah terjabarkan dalam konsidran menim- 
bang dan materi muatan yang ada dalam batang tubuh. Khusus dalam UU 8 Tahun 2016 diatur dalam Pasal 27 yang dengan tegas menyebutkan bahwa Pemerintah wajib dalam pemenuhan hak penyandang disabilitas. Selanjutnya Pemerintah juga wajib menuangkan dalam rencana induk sebagai bentuk dalam rangka pemenuhan hak penyandang disabilitas.

Pemenuhan hak penyandang disabilitas merupakan bentuk kewajiban Pemerintah dalam menjamin dan melindungi penyandang disabilitas. Penyandang disabilitas sebagai subjek hukum berhak diperlakukan sama dan setara sebagaimana terkandung dalam asas kesetaraan yaitu bahwa dalam berbagai kesempatan di berbagai sistem dalam masyarakat dan lingkungan harus mengakomodasi semua orang termasuk para kaum difabel.

Di dalam konteks kesetaraan dalam pemenuhan hak penyandang disabilitas, bukan hanya menjadi tugas Pemerintah melainkan termasuk menjadi kewajiban seluruh lapisan masyarakat dalam pemenuhan hak asasi penyandang disabilitas. Pada prinsipnya dalam pemenuhan hak penyandang disabilitas haus dilakukan secara bersama baik dari pemerintah maupun masyarakat. Ada pandangan masyarakat yang menganggap bahwa para penyandang disabilitas merupakan mahluk yang lemah karena keterbatasan fisik sehingga selalu memerlukan bantuan dan dianggap tidak mampu. Dalam konteks ini para penyadang disabilitas tidak mau dikatakan demikian, mereka hanya membutuhkan akses untuk para penyandang disabilitas dan kesempatan yang sama dalam segala bidang bukan rasa kasihan (Rapindowaty dan Bustanuddin, 2015).

Adapun bentuk-bentuk pemenuhan hak penyandang disabilitas diatur dalam UU 8 Tahun 2016, ditentukan bahwa pemerintah dalam pemenuhan hak-hak penyandang disabilitas dapat berbentuk: pemenuhan hak dalam bidang Keadilan dan Perlindungan Hukum; Pendidikan; Pekerjaan, Kewirausahaan dan Koperasi; Kesehatan; Politik; Keagamaan; Keolahragaan; Kebudayaan dan Pariwisata; Kesejahteraan Sosial; Infrastruktur; Pelayanan Publik; Perlindungan dari benca- na; Rehabilitasi; Pendataan; Komunikasi dan Informasi serta Perlindungan dari tindakan diskriminasi, Penelantaran, Penyiksaan dan eksploitasi.

Dalam konteks itu, Pemerintah wajib membuka akses dan kesempatan bagi terpenuhinya hak penyandang disabilitas. Pengaturan pemenuhan hak penyandang disabilitas juga diatur dalam Peraturan Daerah Provinsi Bali Nomor. 9 Tahun 2015. Selanjutnya pemenuhan hak penyandang disabilitas diatur dalam Pasal 5 yang menentukan bahwa bentuk pemenuhan hak penyandang disabilitas meliputi: pemenuhan hak di bidang pendidikan, ketenagakerjaan, kesehatan, seni budaya dan olah raga, keagamaan dan adat, pemberitaan, politik, bantuan hukum, penanggulangan bencana, tempat tinggal dan rehabilitasi.

Di dalam konteks pemenuhan hak para penyandang disabilitas tidak boleh ada diskriminasi, harus diperlakukan setara. Dalam konteks pemenuhan hak di bidang pendidikan, Pemerintah Provinsi Bali wajib menyediakan sarana di bidang pendidikan seperti sekolah luar biasa (insklusif) yang merupakan sekolah khusus penyandang disabilitas. Tidak saja sekolah yang dipersiapkan, para pendidik juga perlu disiapkan oleh pemerintah daerah. Di dalam menjadi guru pembimbing penyandang disabilitas dalam pendidikan insklusif dilakukan pelatihan kelompok kerja tenaga pendidik sebagaimana diatur dalam Pasal 8 Peraturan Daerah Provinsi Bali Nomor 9 Tahun 2015.

Berkaitan dengan pemenuhan hak penyandang disabilitas yang telah diatur secara legal formal dalam Peraturan Daerah Provinsi Bali Nomor 9 Tahun 2015, perlu dicermati dalam konteks implementasinya. Pencermatan terhadap pemenuhan hak penyandang disabilitas dalam kenyataan ternyata tidak sesempurna seperti yang telah diatur dalam Peraturan Daerah Provinsi Bali Nomor 9 Tahun 2015. Dengan demikian perlu dilakukan kajian secara empiris untuk melihat keberlakuan atau bekerjanya Peraturan Daerah Provinsi Bali Nomor 9 Tahun 2015 dalam masyarakat.

Menarik juga dicermati Pasal 50 Peraturan Daerah Provinsi Bali Nomor 9 Tahun 
2015, yang tegas mengatur mengenai hak penyandang disabilitas di bidang keagamaan dan adat, bahwa berdasarkan pengamatan ada ketimpangan terkait dengan kebreadaan penyandang disabilitas yang berkaitan dengan penlaksanaan keagamaan dan adat di Bali. Ada kepercayaan dalam masyarakat di Bali, bahwa ketika diselenggarakan upacara keagamaan, maka para yang cacat fisik maupun mental atau penyandang disabilitas tidak diijinkan mengikuti upacara keagaamaan. Keadaan seperti ini nampaknya sangat tidak merespon pemenuhan ham bagi para penyandang disabilitas. Terhadap keberadaan seperti ini perlu dicarikan solusi agar para penyandang disabilitas dapat dipenuhi haknya dalam melakukan kegiatan keagamaan.

Pemenuhan hak penyandang disabilitas di bidang bantuan hukum juga menjadi perhatian, mengingat secara prinsip Pemerintah Daerah mempunyai kewajiban dalam memberikan bantuan hukum apabila penyandang disabilitas berhadapan dengan hukum. Berdasarkan penelusuran bahan hukum, bahwa Pemerintah Provinsi Bali belum memiliki Perda tentang Bantuan Hukum, sehingga tampaknya sulit untuk merealisasikan pemenuhan hak penyandang disabilitas di bidang bantuan hukum. Hal ini juga nampaknya menjadi kendala dalam pemenuhan hak-hak penyandang disabilitas di bidang bantuan hukum sebagaimana diatur dalam Pasal 58 Peraturan Daerah Provinsi Bali Nomor 9 Tahun 2015. Berdasarkan pemahaman yang telah diuraikan, nampak apa yang telah diatur secara legal formal mengenai pemenuhan hak penyandang disabilitas di dalam Peraturan Daerah Provinsi Bali Nomor 9 Tahun 2015, masih ada problem di norma dikarenakan ada beberapa norma yang memang tidak dapat diterapkan secara maksimal seperti hak penyandang disabilitas terhadap keagamaan dan adat dan hak untuk mendapatkan bantuan hukum. Sehingga norma Pasal tersebut menjadi norma pasal yang tidak dapat diterapkan secara optimal atau norma Pasal semu.

\section{Simpulan}

Berdasarkan uraian dalam pembahasan maka dapat disimpulkan sebagai berikut.
Pertama, pengaturan perlindungan dan pemenuhan hak bagi penyandang disabilitas di Bali, diatur dengan Peraturan Daerah Provinsi Bali Nomor 9 Tahun 2015 tentang Perlindungan dan Pemenuhan Hak Penyandang Disabilitas. Materi muatan Perda tersebut secara tegas memberikan perlindungan dan pemenuhan hak penyandang disabilitas yang terdiri dari kesamaan kesempatan, akses dan rehabilitasi. Selain memuat hak penyandang disabilitas, Perda tersebut juga memuat kewajiban dari Pemerintah Daerah dalam melakukan pemenuhan hak penyandang disabilitas.

Kedua, meskipun sejumlah hak penyandang disabilitas terjamin melalui perda, namun pemenuhan sebelas hak penyandang disabilitas tertuang dalam Pasal 5 Peraturan Daerah Provinsi Bali Nomor 9 Tahun 2015 masih mengalami kendala dalam pelaksanaannya, terutama menyangkut hak keagamaan dan adat yang mengalami benturan di lapangan, sehingga pemerintah daerah perlu melakukan evaluasi terhadap persoalan inkonsistensi hak-hak keagamaan dengan adatistiadat Bali.

\section{Daftar Pustaka}

Atmaja, Gede Marhaendra Wija, 2012 "Politik Pluralisme Hukum dalam Pengakuan Kesatuan Masyarakat Hukum Adat dengan Peraturan Daerah", Disertasi Doktor, Program Doktor Ilmu Hukum Fakultas Hukum Universitas Brawijaya, Malang

Cohen, Morris L. dan kent C. Olson, 2000, Legal Research in A Nutshell, Seventh Edition, ST. Paul, Minn, West Group.

Degener, Theresia, "International Disability Law- A New Legal Subject on the Rise", Berkeley Journal of International Law, Volume 18, Issue 1, 2000, California.

Hadjon, Philipus M., 1987. Perlindungan Hukum Bagi Rakyat Indonesia, Surabaya: Bina Ilmu.

Hamidi, Jazim, 2016, "Perlindungan Hukum terhadap Disabilitas dalam Memenuhi Hak Mendapatkan Penidikan dan Pekerjaan", Jurnal Hukum, No. 21 April 2012, Fakultas Hukum, UII.

Huda, Ni'Matul, 2006, "Kedudukan Peraturan Daerah Dalam Hirarki Peratuttran Perundang-undangan", Jurnal Hukum No. 1 Vol. 13 Januari 2006, Fakultas Hukum, UII.

Irianto, Sulistyowati, 2009, "Memperkenalkan Studi Sosiolegal dan Implikasi Metodologisnya", dalam Metode Penelitian Hukum Konstelasi dan Refleksi, Editor Sulistyowati Irianto \& Shidarta, Jakarta: Yayasan Obor Indonesia. 
Istiqamah, Destri Tsuraya, "Mendorong Pemenuhan Hak-Hak Penyandang Disabilitas", http://lbhbandung.org, diakses 15 Mei 2016.

Kamus Besar Bahasa Indonesia Pusat Bahasa , 2008, Edisi Ke empat, Departemen Pendidikan Nasional: Gramedia, Jakarta.

Kelsen, Hans, 1973, General Theory of Law and State, Translate by Anders Wedberg, Russell, New York.

Manan, Bagir, 2004, Teori dan Politik Konstitusi, FH UII Press Yogyakarta.

Marzuki, Peter Mahmud, 2005, Peneitian Hukum, Cetakan ke-1, Jakarta: Kencana.

Rahardjo, Satjipto, 1983, Permasalahan Hukum di Indonesia, Bandung: Alummni.

Ranggawidjaja, Rosjidi, 1996, Pedoman Teknik Perancangan Peraturan Perundang-undangan, Bandung: Cita Bhakti Akademika.

Repindowaty, Rahayu dan Bustanuddin, "Perlindungan Hukum Terhadap Penyndang Disabilitas Menurut Convention On The Rights Of Persons With Disabilities (CRPD)", Jurnal Inovatif, Volume VIII Nomor 1 Januari 2015.

Shidarta, Bernard Arief, 2009, "Penelitian Hukum Normatif: Analisis Filosofikal dan Dogmatikal", dalam Metode Penelitian Hukum Konstelasi dan Refleksi, editor Sulistyowati Irianto \& Shidarta,
Yayasan Obor Indonesia, Jakarta.

Soekanto, Soerjono, 1986, Pengantar Penelitian Hukum, Jakarta: Universitas Indonesia (UI) Press).

Waluyo, Bambang, 1991, Penelitian Hukum Dalam Praktek, Sinar Grafika, Jakarta.

Zein, Yahya Ahmad, Problematika Hak Asasi Manusia, Jakarta. http://www.centroone.com/ news/2012/07/2m/pemda-harus-jamin-hak pilihpenyandang-cacat/printpage, diakses tanggal 19 Mei 2016.

Peraturan Perundang-undangan

Undang-Undang Dasar Negera Republik Indonesia Tahun 1945.

Undang-Undang Nomor 19 Tahun 2011 tentang Pengesahan Convention On The Rights Of Persons With Disabilities (Konvensi Mengenai Hak-Hak Penyandang Disabilitas).

Undang-Undang Nomor 8 Tahun 2016 tentang Penyandang Disabilitas.

Putusan MK Nomor 10-17-23/PUU-VII/2009 perihal Pengujian Undang-Undang Nomor 44 Tahun 2008 tentang Pornografi terhadap Undang-Undang Dasar Negara Republik Indonesia Tahun 1945.

Peraturan Daerah Provinsi Bali Nomor 9 Tahun 2015 Tentang Perlindungan dan Pemenuhan Hak Penyandang Disabilitas. 